\title{
Analisis Pengaruh Refluks dan Jumlah Tray Kolom Distilasi Dalam Proses Purifikasi Green Diesel
}

\author{
Tania Oktavia $^{* 1}$, Lutpi Dwi Kurniawan², Ahmad Zikri ${ }^{3}$, Erlinawati ${ }^{4}$, K.A Ridwan ${ }^{5}$ \\ 1,2,3,4,5Program Studi Teknik Energi, Jurusan Teknik Kimia, \\ Politeknik Negeri Sriwijaya, Indonesia \\ Email: ${ }^{1}$ taniaokv@gmail.com, ${ }^{2}$ lutpidk@gmail.com
}

\begin{abstract}
Abstrak
Green Diesel merupakan salah satu sumber energi alternatif yang dapat diperbaharui dan mampu mengurangi ketergantungan energi nasional terhadap energi fosil. Hal ini dikarenakan green diesel dapat diproduksi dari minyak nabati dan limbah seperti minyak jelantah dengan proses hidrogenasi trigliserida menggunakan reaktor hydrotreating. Secara karakteristik minyak jelantah dapat digunakan sebagai bahan baku pembuatan green diesel karena mengandung trigliserida dan asam lemak bebas. Namun dari hasil green diesel yang diproduksi masih banyak mengandung fraksi selain diesel, sehingga masih perlu dilakukan proses pemisahan. Proses pemisahan yang dilakukan yaitu dengan menggunakan kolom distilasi bubble cap tray. Pada penelitian ini dilakukan 2 kali percobaan yaitu distilasi menggunakan refluks dan distilasi tanpa refluks dengan variasi masing-masing jumlah tray $\left(1,2,3\right.$, dan 4 tray) menggunakan $1500 \mathrm{ml}$ crude green diesel dengan temperatur boiler $260^{\circ} \mathrm{C}$, temperatur kondensor dan refluks $10^{\circ} \mathrm{C}$. Waktu operasi yang digunakan 90 menit pada tiap variasi. Dari hasil penelitian, diperoleh kondisi optimum proses distilasi green diesel yaitu distilasi dengan refluks pada tray 1. Adapun hasil analisa karakteristik distilat berupa green diesel yaitu densitas sebesar $0,815-0,830 \mathrm{gr} / \mathrm{cm}^{3}$, viskositas kinematik sebesar sebesar $2,70-2,72 \mathrm{~mm}^{2} / \mathrm{s}$, titik nyala sebesar $55-57,8^{\circ} \mathrm{C}$, nilai kalor sebesar $44,95 \mathrm{MJ} / \mathrm{kg}$ atau 10736,4051 $\mathrm{Cal} / \mathrm{gr}$, dan cetane number sebesar 100,7 CN. Dari hasil analisa tersebut produk green diesel yang dihasilkan telah memenuhi standar Green Diesel European Standards EN15940:2016/A1:2018.
\end{abstract}

Kata kunci: Green Diesel, Kolom Distilasi, Refluks, Tray.

\section{Analysis of The Effect of Reflux and The Number of Trays on The Distillation Column in The Green Diesel Purification}

\begin{abstract}
Green Diesel is one of the alternative energy sources that can be renewed and is able to reduce national energy dependence on fossil energy. This is because green diesel can be produced from vegetable oil and waste such as used cooking oil by hydrogenating triglycerides using a hydrotreating reactor. Characteristically used cooking oil can be used as raw material for making green diesel because it contains triglycerides and free fatty acids. However, from the green diesel produced, there are still many fractions other than diesel, so the separation process still needs to be done. The separation process is carried out by using a bubble cap tray distillation column. In this study, 2 experiments were carried out, namely distillation using reflux and distillation without reflux with variations of each number of trays (1,2,3, and 4 trays) using $1500 \mathrm{ml}$ of crude green diesel with a boiler temperature of $260^{\circ} \mathrm{C}$, condenser temperature and reflux temperature by $10^{\circ} \mathrm{C}$. The operating time used is 90 minutes for each variation. From the results of the study, it was found that the optimum conditions for the green diesel distillation process were distillation with reflux on tray 1. The results of the analysis of the characteristics of the distillate in the form of green diesel were the density of $0.815-0.830 \mathrm{gr} / \mathrm{cm} 3$, the kinematic viscosity of 2.70 $-2.72 \mathrm{~mm} 2 / \mathrm{s}$, a flash point of $55-57.80 \mathrm{C}$, a heating value of $44.95 \mathrm{MJ} / \mathrm{kg}$ or $10736.4051 \mathrm{Cal} / \mathrm{gr}$, and a cetane number of 100.7 CN. From the results of the analysis, the green diesel products produced have met the Green Diesel European Standards EN15940:2016/A1:2018.
\end{abstract}

Keywords: Distillation Column, Green Diesel, Reflux, Tray.

\section{PENDAHULUAN}

Pertumbuhan jumlah penduduk, ekonomi dan pola konsumsi energi yang semakin meningkat membuat kebutuhan energi Indonesia selalu mengalami peningkatan tiap tahunnya (Sa'adah dkk, 2017). Menurut Humas 
SKK Migas tingkat konsumsi bahan bakar minyak secara nasional mencapai 1,6 juta barel per hari, sedangkan kemampuan produksi hanya 834 ribu barel per hari. Sementara cadangan bahan bakar fosil di alam semakin menipis [1]. Semakin berkurangnya sumber energi minyak bumi dan semakin meningkatnya kebutuhan energi merupakan permasalahan energi yang harus diselesaikan. Green diesel adalah salah satu alternatif solusi pemecahan masalah kebutuhan energi tersebut, yaitu dengan mengganti diesel dari minyak bumi dengan minyak yang setara dengan diesel yang diolah dari minyak nabati seperti minyak biji kapuk, minyak jarak dan limbah restoran seperti minyak jelantah. Secara karakteristik minyak jelantah dapat digunakan sebagai bahan baku pembuatan green diesel, karena mengandung trigliserida dan asam lemak bebas seperti minyak kelapa sawit [2].

Komposisi kimia green diesel berdasarkan analisis Gas Chromatography $\neg$ Mass Spectroscopy (GC-MS) didominasi dengan diesel yang mempunyai jumlah atom karbon $\mathrm{C}_{15}-\mathrm{C}_{18}$ sebanyak 59,47\%, sedangkan komposisi lainnya adalah gasoline, kerosine, dan nafta sebanyak 17,15\%, minyak pelumas sebanyak $0,98 \%$, parafin sebanyak 0,55\% dan komponen lainya sebanyak 21,87\% [3]. Dari hasil analisis tersebut, produk green diesel masih belum memiliki indeks kemurnian yang tinggi. Hal ini menunjukan produk yang dihasilkan perlu dilakukan proses lanjutan atau destilasi. Distilasi digunakan untuk memisahkan komponen di dalam larutan yang mempunyai titik didih (volatilitas) yang berbeda baik untuk larutan partial miscible (larut sebagian) maupun miscible (saling larut) menjadi komponennya masing-masing. Ketika campuran komponen dipanaskan, maka uap akan didominasi komponen yang mudah menguap.

Rangkaian alat distilasi yang banyak digunakan adalah jenis tray tower dan packed tower. Tray digunakan untuk memperbesar kontak antara cairan dan gas sehingga komponen dapat dipisahkan sesuai dengan rapat jenisnya, dalam bentuk gas atau cairan. Tray dipakai secara luas di dalam kolom distilasi karena mudah dalam proses desain dan hanya memerlukan biaya yang relatif kecil. Jenis dari tray adalah sieve tray, valve tray, dan bubble cap. Adapun jenis tray yang digunakan pada proses purifikasi ini adalah bubble cap. Pengaruh jumlah tray pada kolom distilasi berpengaruh terhadap kualitas produk distilat. Semakin banyak jumlah tray maka akan semakin tinggi konsentrasi produk yang dihasilkan.

Temperatur pada proses destilasi dilakukan dengan cara menentukan boiling point (titik didih) dari masingmasing fraksi. Green diesel mempunyai jumlah atom karbon $\mathrm{C}_{15}-\mathrm{C}_{18}$ yang memiliki titik didih $250^{\circ} \mathrm{C}-400^{\circ} \mathrm{C}$ [1]. Apabila ditinjau dari kebutuhan mesin dan kebutuhan proses, temperatur distilasi yang optimal pada green diesel adalah $260^{\circ} \mathrm{C}-330^{\circ} \mathrm{C}$ [4]. Salah satu faktor yang mempengaruhi proses distilasi adalah adanya refluks. Refluks merupakan kembalinya cairan atau uap untuk mengadakan kontak ulang dengan fasa uap maupun fasa cairannya dalam kolom. Dengan adanya refluks akan berpengaruh pada konsentrasi hasil destilat (produk atas) sehingga semakin tinggi.Penggunaan refluks juga harus disesuaikan agar dapat menghasilkan pemisahan campuran yang efektif dan efisien. Rasio refluks yang terlalu kecil dapat menyebabkan terjadinya pemisahan komponen yang tidak tepat, sehingga akan menghasilkan fraksi yang belum murni karena masih memiliki kandungan komponen lain yang tidak diinginkan. Sedangkan rasio refluks yang terlalu besar akan menghasilkan pemisahan komponen yang berlangsung lambat dan tidak efisien [5].

Penelitian mengenai purifikasi green diesel masih sangat sedikit yang dilakukan. Sehingga, belum banyak ditemukan kondisi operasi kolom distilasi yang paling optimal dalam meningkatkan mutu green diesel, khususnya yang mengkaji penggunaan refluks dan pengaruh jumlah tray. Oleh karena itu perlu dilakukan penelitian untuk mengetahui pengaruh refluks dan jumlah tray pada proses distilasi fraksinasi terhadap karakteristik dan mutu green diesel yang diharapkan memiliki kadar diesel $\left(\mathrm{C}_{15}-\mathrm{C}_{18}\right)$ yang tinggi.Berdasarkan permasalahan di atas, dilakukan penelitian terhadap proses purifikasi green diesel dengan menggunakan alat kolom distilasi bubble cap tray dengan meninjau pengaruh refluks dan jumlah tray yang digunakan berdasarkan karakteristik green diesel sesuai standar Green Diesel European Standards EN15940:2016/A1:2018.

\section{METODE PENELITIAN}

Penelitian ini dilakukan di Laboratorium Jurusan Teknik Kimia Politeknik Negeri Sriwijaya Palembang. Green diesel yang diproduksi dari reaktor hydrotreating masih banyak mengandung fraksi selain diesel. sehingga masih perlu dilakukan proses pemisahan. Proses pemisahan yang dilakukan yaitu dengan menggunakan kolom distilasi bubble cap tray. Green Diesel yang diproduksi masih banyak mengandung bahan-bahan kimia lain di dalamnya sehingga dibutuhkan suatu proses yang mampu memisahkan bahan-bahan kimia tersebut. Pada penelitian ini penulis menggunakan proses distilasi untuk memisahkan bahan-bahan kimia tersebut.

Dalam penelitian ini digunakan seperangkat alat distilasi yang mampu memisahkan fraksi-fraksi green diesel yang lebih murni. Green diesel dimurnikan dengan alat distilasi yang memiliki variasi penggunaan tray, tray disini berfungsi sebagai tempat kontak antara fase gas dan fase cair. Dan juga pada proses distilasi ini menggunakan refluks. Tahapan distilasi dilakukan pertama kali merangkai seperangkat alat distilasi dengan menvariasikan jumlah tray dan juga menggunakan refluks dan tanpa refluks kemudian umpan dimasukan kedalam reboiler sebanyak $1500 \mathrm{ml}$ dan dipanaskan dengan suhu $260^{\circ} \mathrm{C}-280^{\circ} \mathrm{C}$ selama satu jam. Kemudian hasil distilasi dianalisa 
karakteristiknya yaitu adalah analisis Densitas (ASTM D-1298), Viskositas (ASTM D-1298), Titik Nyala (ASTM D-93), Angka Setana, Nilai Kalor, GC-MS

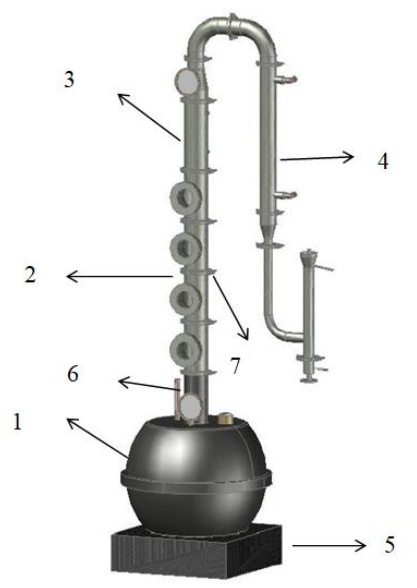

$$
\begin{aligned}
& \text { Keterangan: } \\
& \text { 1. Boiler } \\
& \text { 2. Kolom Distilasi } \\
& \text { 3. Refluks } \\
& \text { 4. Kondensor } \\
& \text { 5. Kompor Gas } \\
& \text { 6. Termometer } \\
& \text { 7. Clamp }
\end{aligned}
$$

Gambar 1. Rangkaian Alat Distilasi

Isi Metode Penelitian umumnya hanya mencakup 20-30\% dari keseluruhan pa Dalam penelitian ini, parameter yang akan diambil terdiri dari variabel tetap dan tidak tetap. Variabel tetap berupa volume crude green diesel, temperatur boiler, temperatur kondensor dan refluks, serta waktu operasi distilasi. Variabel tidak tetap berupa jumlah tray (1,2,3 dan 4 tray) dan penggunaan refluks/tanpa refluks pada proses distilasi. Parameter akan diamati pada proses purifikasi crude green diesel berbahan dasar minyak jelantah melalui proses hydrotreating adalah volume distilat yang dihasilkan berdasarkan jumlah tray yang digunakan serta pengaruh penggunaan refluks pada proses ditilasi berdasarkan karakteristik green diesel yang dihasilkan. Adapun perlakuan percobaan yang akan dilakukan adalah sebagai berikut:

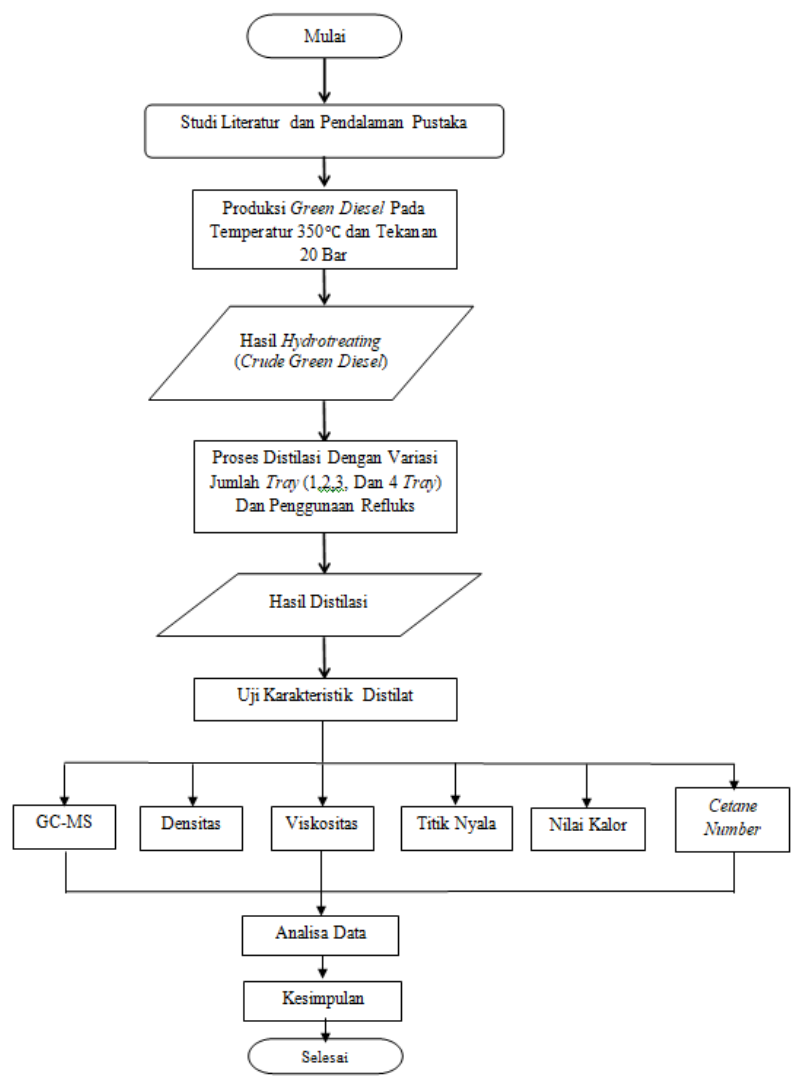

Gambar 2. Diagram Penelitian 


\section{HASIL DAN PEMBAHASAN}

\subsection{Karakteristik Green Diesel yang Dihasilkan}

Green Diesel dari proses distilasi yang dihasilkan memiliki wujud cair dan berwarna bening kekuningan, sebelum dilakukan distilasi bahan baku berwarna coklat kehitaman, hal ini juga menunjukkan proses distilasi terbilang berhasil, dengan nilai densitas sebesar $0,830 \mathrm{gr} / \mathrm{cm}^{3}$, viskositas sebesar $2,70 \mathrm{~mm}^{2} / \mathrm{s}$, titik nyala sebesar $57,8^{\circ} \mathrm{C}$, nilai kalor sebesar 44,9 MJ/kg, dan angka setana sebesar 100,7 CN. Semua hasil analisa diatas stelah menunjukkan keberhasilan distilasi karena sesuai standar Green Diesel European Standard EN15940:2016 /A1:2018. Semakin tinggi densitas maka diameter tetesan bahan bakar dan menghambat proses atomisasi [5]. Semakin tinggi nilai kalor suatu bahan bakar maka energi yang dihasilkan pun akan semakin efisien, karena menghasilkan panas yang lebih besar dengan massa yang sedikit [6].

\subsection{Pengaruh Refluks dan Jumlah Tray Kolom Distilasi Terhadap Volume Distilat}

Pada proses distilasi dilakukan dua tahap percobaan yaitu proses distilasi tanpa menggunakan refluks dan kemudian distilasi dengan menggunakan refluks. Hal ini bertujuan untuk menentukan operasi distilasi yang paling optimum untuk mendapatkan kualitas green diesel terbaik. Berdasarkan penelitian yang dilakukan, pada kondisi distilasi tanpa refluks dihasilkan distilat sebanyak $885 \mathrm{ml}$ sedangkan distilasi dengan refluks menghasilkan sebanyak $825 \mathrm{ml}$. Penggunaan refluks mengakibatkan pemanasan berulang terhadap kondensat yang dihasilkan sehingga pada waktu dan kondisi operasi yang sama, sebagian hasil distilat kembali ke dalam tray untuk dikontakkan kembali sehingga distilat yang dihasilkan memiliki konsentrasi yang lebih tinggi namun dengan kuantitas yang lebih kecil. Dengan adanya refluks, pemisahan kolom untuk crude green diesel semakin baik. Hal ini dapat ditinjau dari volume air yang merupakan produk yang memiliki titik didih rendah yang terkandung dalam crude green diesel dapat terkondensasi pada tray ke 4 sebanyak 90ml hingga ke percobaan tray 3 sebanyak $30 \mathrm{ml}$ sehingga seluruh kandungan air sudah terkondensasi sedangkan pada distilasi tanpa refluks air masih terdapat pada distilat di tray 2.Pada bagian ini dapat diuraikan mengenai hasil dari penelitian beserta pengujian yang telah dilakukan. Selain itu, disampaikan juga mengenai pembahasan dari penelitian maupun pengujian yang telah dilakukan. Hasil analisa dapat dilihat pada grafik yang disajikan pada Gambar 3.

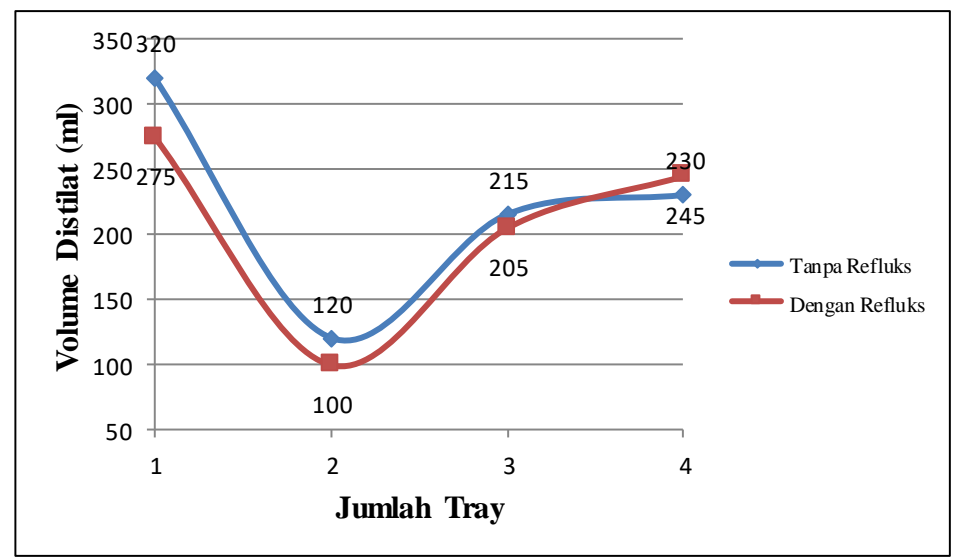

Gambar 3. Grafik Hubungan Jumlah Tray Terhadap Volume Produk

\subsection{Pengaruh Refluks dan Jumlah Tray Kolom Distilasi Terhadap Densitas Distilat}

Densitas dari green diesel berkisar antara 0,765-0,8 $\mathrm{gr} / \mathrm{cm}^{3}$ (Green Diesel European Standards EN15940:2016/A1:2018). Sedangkan diesel dengan jumlah atom karbon $\mathrm{C}_{15}-\mathrm{C}_{18}$ pada SNI 8220:2017 berkisar antara 0,82-0,84 gr/ $\mathrm{cm}^{3}$. Berdasarkan hasil penelitian yang paling mendekati densitas green diesel adalah distilat pada tray 1 yang memiliki densitas sebesar $0,815 \mathrm{gr} / \mathrm{cm}^{3}$ untuk distilasi tanpa refluks dan $0,830 \mathrm{gr} / \mathrm{cm}^{3} \mathrm{untuk}$ distilasi mengggunakan refluks. Pada masing-masing tray memiliki distilat dengan densitas yang berbeda, pada tray 2 memiliki nilai sebesar $0,765 \mathrm{gr} / \mathrm{cm}^{3}$ dan $0,782 \mathrm{gr} / \mathrm{cm}^{3}$ di mana pada proses distilasi tanpa refluks densitas distilat masih merujuk ke gasoline sedangkan pada distilasi menggunakan refluks densitasnya mendekati kerosene. Adapun dengan distilat pada tray 3 dengan masing-masing densitas sebesar $0,712 \mathrm{gr} / \mathrm{cm}^{3} \mathrm{dan} 0,720 \mathrm{gr} / \mathrm{cm}^{3} \mathrm{masih}$ berada dalam range gasoline dengan densitas $0,71-0,77 \mathrm{gr} / \mathrm{cm}^{3}$. Sedangkan densitas distilat pada tray 4 pada kedua proses distilasi didapatkan hasil $0,645 \mathrm{gr} / \mathrm{cm}^{3}$ dan $0,653 \mathrm{gr} / \mathrm{cm}^{3}$ di mana paling mendekati densitas petroleum eter yaitu $0,653 \mathrm{gr} / \mathrm{cm}^{3}$. 
Berdasarkan hasil analisa, proses distilasi menggunakan refluks memiliki densitas yang lebih tinggi dibandingkan dengan distilasi tanpa refluks. Dengan adanya refluks masing-masing konsentrasi distilat meningkat akibat jumlah tetesan kondensat yang dikembalikan ke dalam kolom distilasi dan terjadi pemanasan berulang. Sedangkan pada jumlah tray yang digunakan dapat ditinjau bahwa pada proses distilasi dengan 4 tray memiliki densitas yang lebih kecil yaitu $0,645 \mathrm{gr} / \mathrm{cm}^{3}$ dan $0,653 \mathrm{gr} / \mathrm{cm}^{3}$ sedangkan pada penggunaan 1 tray memiliki densitas sebesar $0,815 \mathrm{gr} / \mathrm{cm}^{3}$ dan $0,830 \mathrm{gr} / \mathrm{cm}^{3}$ maka dapat disimpulkan bahwa semakin banyak tray yang digunakan maka berat jenis dari cairan tersebut semakin ringan. Hasil analisa dapat dilihat pada grafik yang disajikan pada Gambar 4.

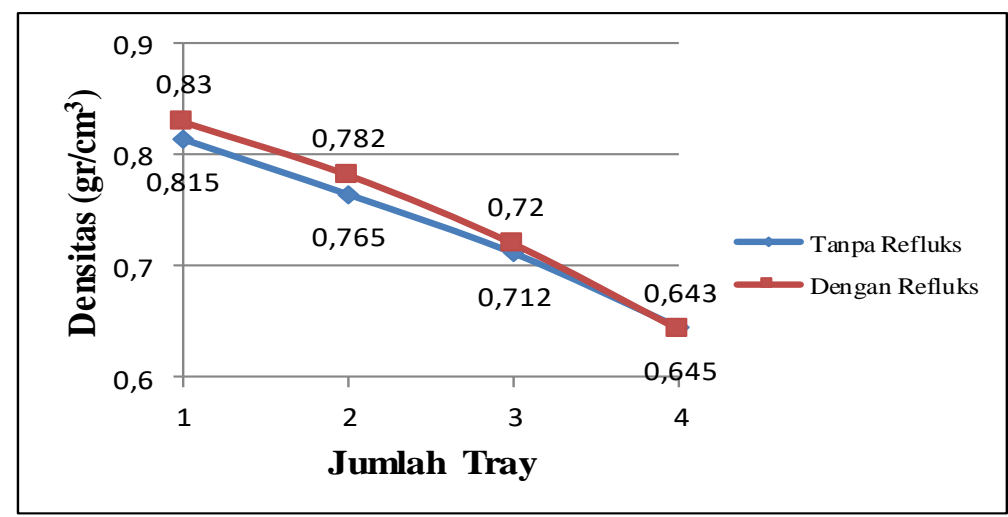

Gambar 4. Grafik Hubungan Jumlah Tray Terhadap Densitas Distilat

\subsection{Pengaruh Refluks dan Jumlah Tray Kolom Distilasi Terhadap Viskositas Distilat}

Viskositas merupakan sifat yang sangat penting dalam penyimpanan dan penggunaan suatu bahan bakar. Viskositas dari bahan bakar green diesel berkisar antara 2,0-4,5 mm2/s (Green Diesel European Standards EN15940:2016/A1:2018). Berdasarkan penelitian, pada proses distilasi tanpa refluks pada tray 1 memiliki viskositas sebesar $2,72 \mathrm{~mm}^{2} / \mathrm{s}$ sedangkan proses distilasi dengan refluks sebesar $2,82 \mathrm{~mm}^{2} / \mathrm{s}$. Di mana pada kedua proses ini sama-sama memiliki kemiripan dengan diesel yang memiliki viskositas $2-4,5 \mathrm{~mm}^{2} / \mathrm{s}$. Kemudian pada tray 2 proses distilasi tanpa refluks memiliki viskositas $2,45 \mathrm{~mm}^{2} / \mathrm{s} \mathrm{di} \mathrm{mana} \mathrm{masuk} \mathrm{kedalam} \mathrm{range} \mathrm{diesel} \mathrm{sedangkan}$ distilasi dengan refluks sebesar $2,39 \mathrm{~mm}^{2} / \mathrm{s}$ yang memiliki kesamaan dengan viskositas kerosene yaitu $2,39 \mathrm{~mm}^{2} / \mathrm{s}$. Pada tray 3 viskositas distilat tanpa refluks sebesar $1,12 \mathrm{~mm} 2 / \mathrm{s}$ dan pada distilat dengan refluks sebesar 0,88 $\mathrm{mm}^{2} / \mathrm{s}$. Pada kedua nilai tersebut mendekati gasoline dengan viskositas $0,652 \mathrm{~mm}^{2} / \mathrm{s}$. Di mana pada distilasi yang mengunakan refluks lebih mendekati dibandingkan tanpa refluks. Adapun pada tray 4 viskositas distilat tanpa refluks sebesar $0,55 \mathrm{~mm}^{2} / \mathrm{s}$ sedangkan viskositas distilat dengan refluks sebesar $0,46 \mathrm{~mm}^{2} / \mathrm{s}$ yang mendekati nilai viskositas petroleum eter yaitu $0,45 \mathrm{~mm}^{2} / \mathrm{s}$.

Viskositas yang rendah memudahkan bahan bakar diinjeksikan, dikabutkan dan dicampur dengan udara sehingga memicu pembakaran yang lebih baik. Sebaliknya, viskositas yang tinggi mengakibatkan atomisasi bahan bakar yang kurang baik sehingga berdampak pada pembakaran yang buruk (Syarifudin, dkk., 2019). Sehingga pengaruh refluks berkontribusi dalam melakukan pemisahan komponen lebih optimal karena dapat ditinjau dari hasil viskositas yang lebih mendekati dari masing-masing jenis pada tiap tray. Hasil analisa dapat dilihat pada grafik yang disajikan pada Gambar 5 .

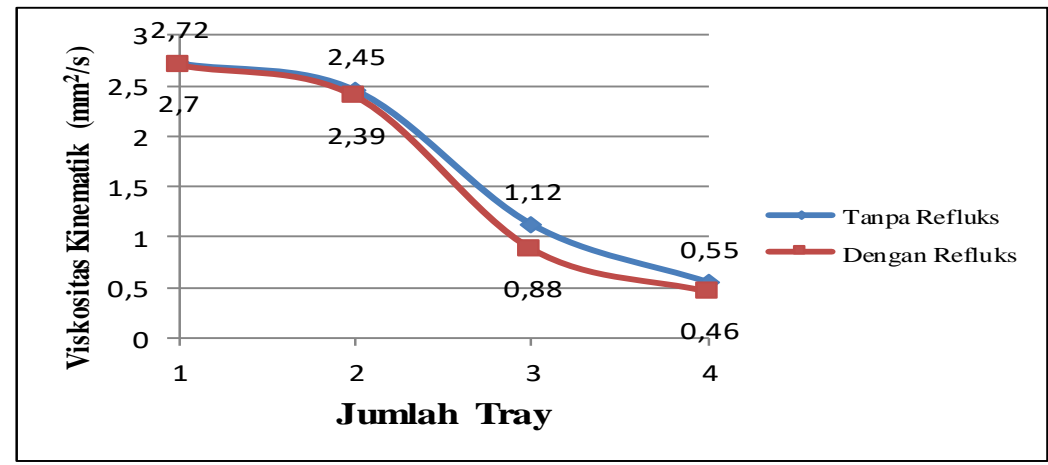

Gambar 5. Grafik Hubungan Jumlah Tray Terhadap Viskositas Distilat 


\subsection{Pengaruh Refluks dan Jumlah Tray Kolom Distilasi Terhadap Titik Nyala Distilat}

Dari hasil pengujian titik nyala yang didapatkan pada tray 1 tanpa refluks sebesar $55^{\circ} \mathrm{C}$ sedangkan pada distilasi dengan refluks sebesar $57,8^{\circ} \mathrm{C}$, keduanya termasuk dalam range diesel. Sedangkan pada tray 2 masingmasing tanpa dan dengan refluks sebesar $38^{\circ} \mathrm{C}$ dan $40^{\circ} \mathrm{C}$ yang mendekati titik nyala dari kerosene yaitu $37^{\circ} \mathrm{C}$. Kemudian pada tray 3 pada proses distilasi tanpa refluks menghasilkan distilat dengan titik nyala sebesar $13,7^{\circ} \mathrm{C}$ dan distilasi dengan refluks sebesar $11,5^{\circ} \mathrm{C}$. Pada tray 4 distilasi tanpa refluks memiliki titik nyala $8^{\circ} \mathrm{C}$ dan distilasi dengan refluks memiliki distilat yang mempunyai titik nyala $5^{\circ} \mathrm{C}$. Pada kedua tray ini memiliki titik nyala yang lebih tinggi dibandingkan titik nyala gasoline maupun petroleum eter namun, hal ini bisa disebabkan karena masih terkandung beberapa fraksi berat sehingga mempengaruhi nilai titik nyalanya.

Berdasarkan penelitian yang dilakukan, semakin banyak jumlah tray yang digunakan makan titik nyala distilat akan semakin kecil. Hal ini disebabkan karena distilat yang dihasilkan semakin ringan atau memiliki jumlah atom $\mathrm{C}$ yang rendah sehingga lebih mudah menyala. Adapun pengaruh refluks yang digunakan pada proses distilasi mengakibatkan titik nyala pada distilat semakin mendekati dengan fraksi yang diduga merupakan jenis distilat yang dihasilkan. Titik nyala yang terlalu tinggi juga dapat menyebabkan keterlambatan penyalaan, namun titik nyala yang terlalu rendah juga tidak diinginkan karena akan menyebabkan timbulnya detonasi yaitu ledakanledakan kecil yang terjadi sebelum bahan bakar masuk ke ruang bakar (Ni'matul Izza, 2011). Hasil analisa dapat dilihat pada grafik yang disajikan pada Gambar 6 .

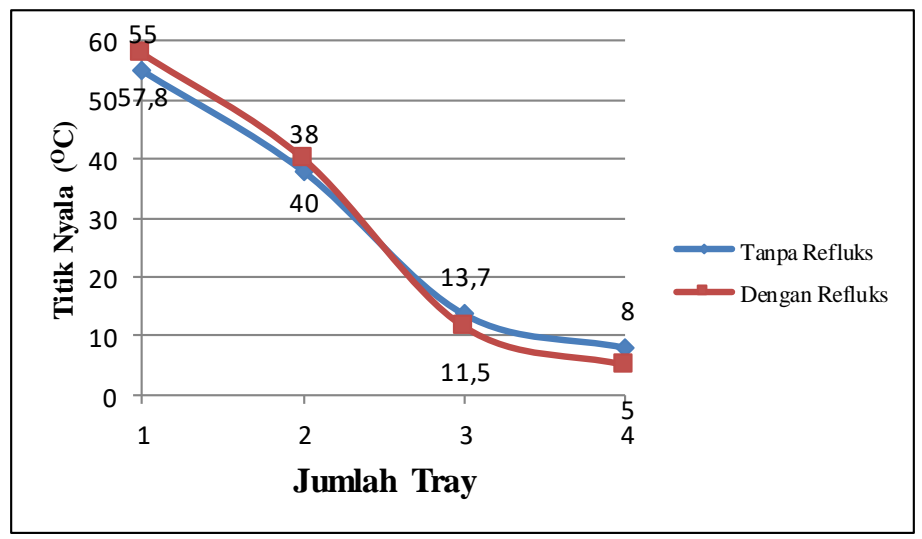

Gambar 6. Grafik Hubungan Jumlah Tray Terhadap Titik Nyala Distilat

\subsection{Analisa Kalor Green Diesel}

Nilai kalor merupakan jumlah energi panas yang dilepaskan tiap satuan massa. Pada penelitian ini, pengukuran nilai kalor dilakukan pada sampel hasil distilasi dengan refluks pada tray 1 . Pengukuran nilai kalor dilakukan dengan menggunakan bomb calorimeter dengan nilai kalor yang didapat sebesar 44,95 MJ/kg atau 10736,4051 cal/gram. Nilai kalor ini mendekati nilai kalor Green Diesel European Standards EN15940:2016 /A1:201 sebesar 43,70-45 MJ/kg. Semakin tinggi nilai kalor suatu bahan bakar maka energi yang dihasilkan pun akan semakin efisien, karena menghasilkan panas yang lebih besar dengan massa yang sedikit [6].

\subsection{Analisa Cetane NumberGreen Diesel}

Pada penelitian ini, pengukuran nilai kalor dilakukan pada sampel hasil distilasi dengan refluks pada tray 1. Pengukuran nilai kalor dilakukan dengan menggunakan Cetane and Fuel Analyzer Zeltex. Angka setana yang didapatkan sebesar 100,7 CN, nilai ini mendekati angka setana Green Diesel European Standards EN15940:2016/A1:201 sebesar 70 CN. Nilai yang didapatkan cukup tinggi sehingga diesel yang dihasilkan dari proses distilasi merupakan green diesel kualitas tinggi.

\subsection{Analisis Senyawa Kimia dan Komposisi Green Diesel}

Pada penelitian ini, dilakukan analisis senyawa kimia dan komposisi green diesel menggunakan Gas Chromatography-Mass Spectrometry (GC-MS) pada sampel hasil distilasi dengan refluks pada tray 1. Dari pengujian menggunakan GC-MS, diasumsikan bahwa hasil analisis senyawa kimia dan komposisi green diesel mewakili keseluruhan sampel green diesel.

Green Diesel dari proses distilasi ini mengandung komposisi senyawa hidrokarbon dengan jumlah rantai $\mathrm{C}$ yang beragam. Dari gambar 6 dapat diketahui bahwa produk yang dihasilkan mengandung rantai $\mathrm{C}_{15}-\mathrm{C}_{18}$ sebagai 
komposisi dominan sebesar 86,29\%, di mana rantai ini merupakan rantai fraksi diesel. Sedangkan komposisi lainnya yaitu, gasoline dan nafta $\left(\mathrm{C}_{5}-\mathrm{C}_{11}\right)$ sebesar $8,71 \%$ dan kerosene $\left(\mathrm{C}_{12}-\mathrm{C}_{15}\right)$ sebesar 5\%. Adanya kandungan gasoline, nafta, dan kerosine $\left(\mathrm{C}_{5}-\mathrm{C}_{15}\right)$ disebabkan karena masih adanya fraksi ringan yang belum teruapkan pada tray sebelumnya. Namun proses purifikasi crude green diesel yang telah dilakukan mampu meningkatkan konsentrasi green diesel sebelum distilasi yaitu dari 59,47\% meningkat hingga 86,29\%.

Green diesel yang dihasilkan tidak mengandung zat-zat yang memiliki fraksi $<\mathrm{C}_{5}$ karena hidrokarbon dibawah $\mathrm{C}_{5}$ merupakan hidrokarbon berfase gas dan sudah terkondensasi pada tray 4, sehingga hanya meninggalkan fraksi yang lebih berat. Berdasarkan data komposisi GC-MS ini dapat disimpulkan bahwa produk green diesel yang dihasilkan memiliki komposisi yang sama dengan bahan bakar diesel. Hasil analisa dapat dilihat pada grafik yang disajikan pada Gambar 7.

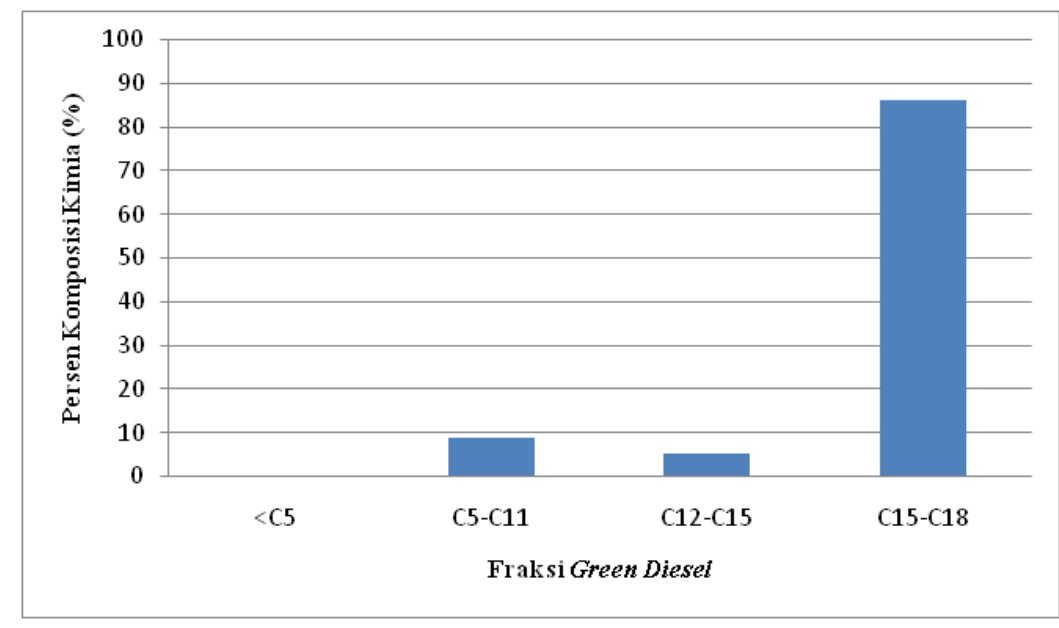

Gambar 7. Grafik Fraksi dan Komposisi Green Diesel

\section{KESIMPULAN}

Kondisi optimum proses purifikasi green diesel yaitu distilasi dengan menggunakan refluks pada temperatur reboiler $260^{\circ} \mathrm{C}$, temperatur refluks dan kondensor $10^{\circ} \mathrm{C}$ serta pada waktu operasi 90 menit dengan banyak umpan 1500ml. Dengan adanya refluks, konsentrasi hasil distilat semakin tinggi. Berdasarkan analisa, green diesel terletak pada tray 1 karena memiliki fraksi yang lebih berat adapun pada tray 2 mendekati karakteristik kerosene, tray 3 dengan gasoline dan tray 4 sebagai petroleum eter. Sehingga proses pemisahan menjadi optimal menggunakan 4 tray secara berurutan hingga 1 tray untuk mendapatkan kualitas green diesel terbaik.Karakteristik produk hasil distilasi menggunakan refluks pada tray 1 yang dihasilkan memiliki sifat yang paling mirip dengan Green Diesel European Standards EN15940:2016/A1:2018 ditinjau dari sifat fisik dan kimianya berupa densitas, viskositas, titik nyala, cetane number dan nilai kalor.

\section{DAFTAR PUSTAKA}

[1] E. Purwanto, "Produksi dan Karakterisasi Minyak Green Diesel dari Pirolisis Minyak Jelantah Berbantuan Gelombang Mikro”, Universitas Negeri Semarang, 2020.

[2] J. Prasetyo, "Studi Pemanfaatan Minyak Jelantah Sebagai Bahan Baku Pembuatan Biodiesel", Jurnal Ilmiah Teknik Kimia UNPAM, vol. 2, no. 2, 2019.

[3] A. Zikri, and M. Aznury, "Green diesel production from Crude Palm Oil (CPO) using catalytic hydrogenation method”, IOP Conference Series: Materials Science and Engineering, vol. 823, no. 1, 2020. https://doi.org/10.1088/1757-899X/823/1/012026

[4] F. S. Emmaputri, S. Nurjanah, E. Mardawati, M. A. M. Kramadibrata, M. Muhaemin, W. Daradjat, H. Handarto, and T. Herwanto, "Kajian Proses Destilasi Fraksinasi Biodiesel Kemiri Sunan (Reutealis trisperma)", Jurnal Teknotan, vol. 12, no. 2, pp. 29, 2019. https://doi.org/10.24198/jt.vol12n2.5

[5] M. Malahayati, and Rahmawati. "Optimasi Tekanan dan Rasio Refluks pada Distilasi Fraksinasi Vakum terhadap Mutu Eugenol dari Minyak Daun Cengkeh (Eugenia caryophyllata)”, Konversi, vol. 3 no. 2 , 2014.

[6] R. Irzon, "Perbandingan Calorific Value Beragam Bahan Bakar Minyak Yang Dipasarkan Di Indonesia Menggunakan Bomb Calorimeter”, JSD.Geol, vol. 22, no. 4, 2012. 
[7] S. L. Douvartzides, N. D. Charisiou, K. N. Papageridis, and M. A. Goula, "Green diesel: Biomass feedstocks, production technologies, catalytic research, fuel properties and performance in compression ignition internal combustion engines", Energies, vol. 12, no. 5, 2019. https://doi.org/10.3390/en12050809

[8] T. N. Kalnes, K. P. Koers, T. Marker, and D. R. Shonnard, "A technoeconomic and environmental life cycle comparison of green diesel to biodiesel and syndiesel", Environmental Progress and Sustainable Energy, vol. 28, no. 1, pp. 111-120, 2009. https://doi.org/10.1002/ep.10319

[9] A. F. Sa'adah, A. Fauzi, and B. Juanda, "Peramalan Penyediaan dan Konsumsi Bahan Bakar Minyak Indonesia dengan Model Sistem Dinamik”, Jurnal Ekonomi Dan Pembangunan Indonesia, vo. 17, no. 2, pp. 118-137, 2017. https://doi.org/10.21002/jepi.v17i2.661

[10] R. Banani, S. Youssef, M. Bezzarga, and M. Abderrabba, "Waste Frying Oil with High Levels of Free Fatty Acids as one of the prominent sources of Biodiesel Production”, J. Mater. Environ. Sci, vol. 6, no. 4, pp. 1178-1185, 2015.

[11] T. Hudaya, and H. Soerawidjaja, "Kajian Peforma Katalis Ni-Mo-S/ $\gamma$-Al2O3Proses Hidrotreating Minyak BijiKapok (Ceiba pentandra) untuk Sintesa Biosolar", Prosiding Seminar Nasional Teknik Kimia “Kejuangan”. 2019.

[12] H. Heriyanto, M. Sumbogo, S. Heriyanti, I. Sholehah, and A. Rahmawati, "Synthesis of Green Diesel from Waste Cooking Oil Through Hydrodeoxygenation Technology with NiMo/ $\gamma-\mathrm{Al} 2 \mathrm{O} 3$ Catalysts", MATEC Web of Conferences, pp. 156, 2018. https://doi.org/10.1051/matecconf/201815603032 